Luciana Botelho Chaves

\title{
Produção de anticorpos monoclonais para caracterização de variantes antigênicas brasileiras de vírus da raiva
}

Tese apresentada ao Programa de PósGraduação Interunidades em Biotecnologia USP/Instituto Butantan/IPT, para obtenção do Título de Doutor em Biotecnologia

Área de concentração: Biotecnologia

Orientadora: Dra. Elizabeth Natal de Gaspari 


\section{RESUMO}

Chaves LB. Produção de anticorpos monoclonais para caracterização de variantes antigênicas brasileiras de vírus da raiva. [tese (Doutorado em Biotecnologia)]. São Paulo (Brasil): Instituto de Ciências Biomédicas Universidade de São Paulo; 2010.

Entre 1987 e 1992, foi produzido um painel com oito anticorpos monoclonais (AcM), a partir de isolados de vários países das Américas, permitindo que mais de 800 destes fossem caracterizados, possibilitando determinar a distribuição geográfica das diferentes variantes antigênicas, descrever novas e identificar outras conhecidas em novos hospedeiros. No Brasil, uma análise feita em 2002, com 330 isolados de diferentes espécies, identificou cinco variantes antigênicas compatíveis com os perfis do painel e seis não compatíveis. Ao longo dos anos, se observou a existência de vários outros isolados com perfis antigênicos distintos aos pré-estabelecidos. O objetivo principal deste estudo foi a produção de hibridomas secretores de AcM contra proteínas do vírus da raiva (RABV) que possam adequar a caracterização antigênica dos isolados no Brasil. Foram selecionadas dois isolados de RABV de morcegos insetívoros que apresentaram perfis não compatíveis com o painel utilizado, sendo um isolado da espécie Nyctinomops laticaudatus (7268V/05) e outro de Eptesicus furinalis (636V/06). As suspensões virais de sistema nervoso central foram adaptadas para crescimento em cultura de células de neuroblastoma murino. Para o preparo de AcM foram utilizadas, como antígeno, as ribonucleoproteínas purificadas dos isolados selecionados. Foram obtidos dois clones estáveis produtores de AcM, o 3A7 e o 4E10. No total dos 57 isolados de RABV analisados com os AcM obtidos o AcM 3A7 reagiu com 21 dos isolados $(36,84 \%)$ e o AcM 4E10 com 25 dos isolados (43,85\%). Dos 13 isolados caracterizados como variante antigênica 3 (Desmodus rotundus) o AcM 3A7 reagiu com oito (61,53\%) e o 4E10 com onze $(84,61 \%)$. Dos nove isolados que apresentaram um perfil não compatível característico de isolados de morcegos insetívoros, o 3A7 reagiu com 5 (55,55\%) e o 4E10 com $4(44,44 \%)$. Os resultados demonstraram que os clones produziram anticorpos que futuramente poderão auxiliar na complementação do painel de AcM que caracterizem o perfil antigênico dos isolados do Brasil, a fim de aprimorar a vigilância epidemiológica.

Palavras-chave: Vírus da raiva. Caracterização antigênica. Anticorpos monoclonais. Morcegos insetívoros. 


\begin{abstract}
Chaves LB. Production of monoclonal antibodies for characterization of Brazilian antigenic variants of rabies virus. [Ph.D. thesis (Biotecnology)]. São Paulo/ Brasil: Instituto de Ciências Biomédicas Universidade de São Paulo; 2010.

Between 1987 and 1992, a panel of eight monoclonal antibodies (MAb) was produced, from isolates from various countries in the Americas, allowing more than 800 of these to be characterized. This made it possible to determine the geographic distribution of the different antigenic variants, to describe new ones and to identify others known in new hosts. In Brazil, an analysis was done in 2002, with 330 isolates from different species, and demonstrated five antigenic variants compatible with the profiles of the panel and six not compatible. Over the years, it was noticed that there were various other isolates with antigenic profiles that differed from pre-established ones. The main aim of this study was to produce hybridomas secreting $\mathrm{MAb}$ against RABV proteins, which can suit the antigenic characterization of the isolates in Brazil. Two RABV isolates from insectivorous bats were selected, which showed noncompatible profiles, where one isolate was from the species Nyctinomops laticaudatus (7268V/05) and the other from Eptesicus furinalis (636V/06). The viral suspensions of the central nervous system were adapted for growth in cultured murine neuroblastoma cells. Ribonucleoproteins purified from selected isolates were used as antigen for the preparation of monoclonal antibodies. We obtained two Mab, the 3A7 and the 4E10. Of the 57 RABV isolates analyzed with these MAb, the 3A7 reacted with 21 (36.84\%) and 4E10 with 25 (43.85\%). Of the 13 isolates characterized as antigenic variant 3 (Desmodus rotundus), the $3 \mathrm{~A} 7 \mathrm{MAb}$ reacted with $8(61.53 \%)$ and 4E10 with $11(84.61 \%)$. Of the nine isolates with the profile non compatible related with insectivorous bats the $3 \mathrm{~A} 7$ reacted with $5(55.55 \%)$ and the $4 \mathrm{E} 10$ with $4(44.44 \%)$. The results demonstrated that the clones produced antibodies that in the future will help in the complementation of the panel of MAb that characterize the antigenic profile of the isolates of Brazil, in order to improve epidemiologic surveillance.
\end{abstract}

Key words: Rabies virus. Antigenic characterization. Monoclonal antibodies. Insectivorous bats. 


\section{INTRODUÇÃO}

\subsection{História da raiva}

A raiva é uma das mais antigas doenças que se tem conhecimento sendo descrita e estudada desde o século 23 a.C. Demócritus (500 a.C.) e Aristóteles (322 a.C.) foram os primeiros a reconhecer a raiva como uma doença de animais. Aristóteles escreveu no livro "História Natural dos Animais" que os cães com raiva ficavam muito irritados e os animais mordidos por aqueles cães também se tornavam raivosos, porém ele acreditava que o ser humano não era acometido pela raiva animal (Theodorides, 1986; Steele, Fernandez, 1991; Baer, 2007).

No $1^{\circ}$ século a.C., Celsius (63 a.C. - 14 d.C.) descreveria sua transmissibilidade ao homem correlacionando a hidrofobia humana à raiva canina, afirmando que toda a mordida poderia conter o "veneno" (em latim "virus") fosse ela causada por outro homem, cão, macaco, ou outro animal selvagem (Dean, Baer, Thompson, 1963; Baer, 2007).

Zinke, em 1804, realizou o primeiro experimento que demonstrava a capacidade infectante da saliva de cães raivosos, quando a inoculou experimentalmente em cães sadios e esses contraíram raiva. Magendie e Breschett, em 1821 infectaram cães com saliva humana e provaram que em ambos os casos estava envolvido o mesmo agente (Zinke, 1803 apud Baer, Belli, Fishbein, 1990).

Em 1881 foram publicados os resultados de Galtier sobre a estabilidade do vírus e as condições de transmissão da doença. Ele foi o primeiro a provar que seria possível induzir proteção contra a raiva, observando carneiros que, após várias injeções de saliva contaminada por via intravenosa, pareciam ter adquirido imunidade. Os experimentos de Zinke e Galtier convenceram as autoridades que a raiva era uma doença infecciosa, associada primariamente a cães e que medidas de controle de animais podiam levar a sua eliminação (Wilkinson, 2002).

Os trabalhos de Galtier, de 1879 a 1904 foram fundamentais para que Pasteur começasse a estudar a doença em 1880 com o objetivo "de revelar e cultivar seu verdadeiro agente etiológico". Por meio da inoculação intracerebral de extratos de cérebro de animais raivosos em animais sadios, certificou-se de que o sistema nervoso central era a principal fonte de vírus. Depois disto realizou estudos para atenuar a patogenicidade do vírus por passagens sucessivas no cérebro de diferentes animais. Observou que o período de incubação da doença, antes muito variável, encurtava progressivamente até se tornar estável. Desta maneira ele obteve o que chamou de "vírus fixo", ao contrário dos "vírus de rua", isolados 
dos animais naturalmente infectados. Em 1884, utilizando porções de medula espinhal de coelhos infectados com vírus previamente modificado, Pasteur conseguiu fazer com que cães se tornassem refratários à doença após inoculação intracerebral. Constatou que dessecação de medulas obtidas de animais infectados durante 2 a 9 dias a $22{ }^{\circ} \mathrm{C}$ em presença de hidróxido de potássio, causava atenuação física do material. Em 1885, Pasteur demonstrou que, após inoculações subcutâneas diárias de uma suspensão de medula de animal infectado dessecada, era possível proteger cães contra um desafio viral por via intracerebral (Baer, 2007).

Em 6 de julho de 1885 Pasteur teve a oportunidade de testar pela primeira vez sua vacina em humanos. Nesse dia apareceu em seu laboratório Joseph Meister, um menino de 9 anos que havia sofrido graves mordeduras de um cão raivoso 2 dias antes. $\mathrm{O}$ menino recebeu em 10 dias 13 injeções de suspensão de medula e sobreviveu (Wilkinson, 2002).

Assim, foi estabelecido o primeiro método de profilaxia pós-exposição, o que desencadeou uma longa sucessão de tratamentos para a raiva e estudos experimentais para se entender o mecanismo imune de defesa do hospedeiro contra a infecção pelo vírus da raiva.

\subsection{O vírus da raiva $-\mathbf{R A B V}$}

\subsubsection{Classificação}

$\mathrm{O}$ vírus da raiva pertence à ordem Mononegavirales, família Rhabdoviridae (Pringle, 1991; Fauquet et al., 2005). A família Rhabdoviridae é composta de vários gêneros, dos quais apenas três infectam mamíferos: o gênero Vesiculovirus, representado pelos vírus causadores da estomatite vesicular (VSV), o gênero Ephemerovirus, causador da febre catarral maligna, e o gênero Lyssavirus, onde se incluem o vírus da raiva (RABV) e os vírus ditos aparentados (rabies-like) (Wunner, 2007).

Ensaios utilizando anticorpos neutralizantes $(\mathrm{AcN})$ que reconheciam as glicoproteínas de membrana do vírus e ensaios com anticorpos monoclonais (AcM) subdividiram o gênero Lyssavirus em 4 sorotipos (Schneider et al., 1973; Wiktor, Flamand, Koprowski, 1980). O sorotipo I, mundialmente distribuído, correspondia às cepas clássicas representadas pelos vírus fixos ou vacinais e por isolados de vírus da maioria dos mamíferos terrestres e de morcegos hematófagos, insetívoros e frugívoros das Américas. Ao sorotipo II correspondia o vírus Lagos Bat, isolado de morcegos e de um gato da região de Lagos na Nigéria, África. Ao sorotipo III correspondia o vírus Mokola, isolado de roedores e de um humano, também na África. O sorotipo IV era representado pelo vírus Duvenhage, isolado de morcegos e humanos, na África (Wiktor, Koprowski, 1980). Os vírus detectados em morcegos insetívoros 
na Europa, denominados "European bat lyssavirus" (EBL tipo 1 e 2) foram identificados como vírus aparentados, porém não foram classificados como novos sorotipos (Schneider, 1982).

Comparações dos genes da nucleoproteína viral (N) e da glicoproteína (G) distinguiram sete genótipos do gênero Lyssavirus, os primeiros quatro correspondentes aos quatro sorotipos já descritos e dois genótipos adicionais foram definidos para o EBL tipo 1 e EBL tipo 2, genótipos V e VI, respectivamente (Bouhry, Kissi, Tordo, 1993). Por fim, o Australian bat lyssavirus responsável por casos humanos na Austrália, estabeleceu um sétimo genótipo (Hooper et al. 1997; Gould et al., 1998; Hanna et al. 2000; King, 2001; Pounder, 2003). Atualmente são sugeridas mais quatro variantes virais, isoladas de morcegos, para constituírem novos genótipos de lissavírus. Em 2003, foi descrita a variante Aravan virus, isolada em 1991 de um morcego insetívoro da espécie Myotis blythi, no Kirgiquistão, Ásia Central (Arai et al., 2003; Kuzmin, Botvinkin, Khabilov, 2001; Kuzmin et al, 2003); a variante Khujand, isolada em 2001, no noroeste do Tajikistão, Ásia Central, também em morcegos insetívoros (Myotis mystacinus) (Kuzmin, Botvinkin, Khabilov, 2001; Kuzmin et al., 2003). As outras duas variantes foram isoladas na Rússia, uma obtida na cidade de Irkutsk, denominada Irkut virus, isolada de um morcego Murina leucogaster e a outra, obtida da região Oeste das montanhas do Cáucaso, denominada West caucasian bat virus, isolada de morcego Miniopterus schreibersi (Botvinkin et al., 2003). No continente americano e no Caribe, até o momento, só foi registrada a presença do genótipo I de Lyssavirus (Fooks, 2004).

A diversidade genética dos membros do gênero Lyssavirus surgiu a partir de modificações dos genes $N$ e $G$, que codificam a nucleoproteína (N) e a glicoproteína (G), respectivamente. Análises filogenéticas distinguiram os sete genótipos, os quais podem ser classificados em dois filogrupos principais de acordo com as características sorológicas e patogênicas. O filogrupo I abrange os genótipos I, IV, V, VI e VII e o filogrupo II os genótipos II e III (Badrane et al., 2001; Rotivel et al., 2002).

O genótipo I é amplamente distribuído mundialmente e tem maior importância epidemiológica dada sua associação com um maior número de casos de encefalite por Lyssavirus em humanos em relação aos outros genótipos.

Estudos moleculares do vírus têm mostrado que existem vários reservatórios para o genótipo I, nos quais linhagens virais adaptadas se mantêm na natureza em ciclos epidemiológicos independentes. Dentro de cada ciclo, estes diferentes reservatórios exercem 
um papel fundamental e específico na manutenção de cada linhagem (Velasco-Villa et al., 2002).

\subsubsection{Estrutura}

O RABV é um vírus neurotrópico, RNA negativo de fita-simples. Apresenta forma cilíndrica, uma estrutura em forma de bala de revólver com aproximadamente $75 \mathrm{~nm}$ de diâmetro por $180 \mathrm{~nm}$ de comprimento, sendo constituído de nucleocapsídeo helicoidal ou ribonucleoproteínas (RNP) e o envelope viral coberto de glicoproteínas espiculadas. O core de RNP é constituído do genoma RNA fita simples encapsidado pela proteína de nucleocapsídeo $(\mathrm{N})$, pela RNA-polimerase (L) e pela fosfoproteína (P). O core RNP associado com a proteína de matriz $(\mathrm{M})$ é condensado na típica forma de bala, característica dos rabdovírus. Um envelope de bicamada lipídica, no qual estão ancoradas na superfície espículas triméricas de glicoproteína (G), envolve a estrutura RNP-M (Figura 1) (Wunner, 2007).

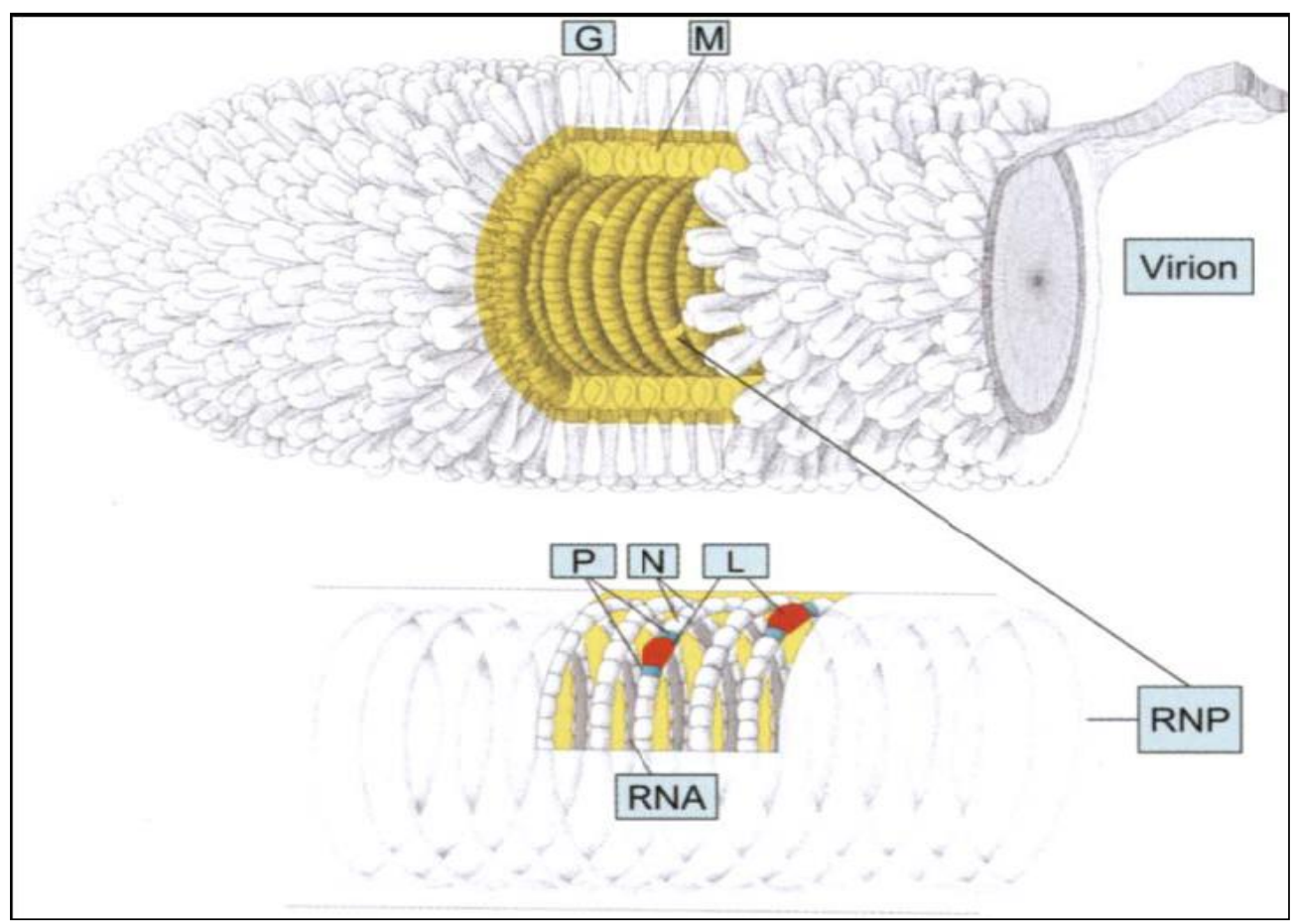

Figura 1. Representação esquemática do vírus da raiva.

RNP: O core de ribonucleoproteínas com genoma RNA fita simples, proteína de nucleocapsídeo (N), RNA-polimerase (L) e fosfoproteína. (P). O core RNP associado com a proteína de matriz (M). Espículas triméricas de glicoproteína (G) envolvem a estrutura RNP-M.

Fonte: Wunner et al, 1988 apud Wunner, 2007. 
As cinco proteínas virais, nucleoproteína $(\mathrm{N})$, fosfoproteína $(\mathrm{P})$, proteína de matriz (M), glicoproteína (G) e a RNA-polimerase (L) são codificadas por cinco genes $N, P, M, G e$ $L$, respectivamente. (Murphy, 1991; Tordo, 1996; Wunner, 2007).

A proteína $\mathrm{N}$ é constituída de 450 aminoácidos (aa) e apresenta massa molecular de aproximadamente $57 \mathrm{kDa}$, sendo o principal componente viral e a principal proteína do nucleocapsídeo. Apresenta a sequência de aa mais conservada entre os sete genótipos dos lissavírus. A conservação genética de $\mathrm{N}$ ao longo do tempo ocorre, provavelmente, pelos seguintes fatos: interage com o RNA capsidando-o; é a mais abundante proteína do capsídeo; protege o genoma contra nucleases celulares; regula a replicação; modula a transcrição e interage com a fosfoproteína $\mathrm{P}$ durante a replicação e tradução (Wunner, 2002). A proteína $\mathrm{N}$ também é a mais conservada antigenicamente, e por estas razões é a mais utilizada em diagnósticos e estudos das relações evolutivas e epidemiológicas (Tordo, Kouknetzoff, 1993). Apesar desta natureza conservada, existe um grau relativamente alto de diversidade genética dentro dos pequenos segmentos do gene $N$ entre os genótipos. As diferenças de aa da $\mathrm{N}$ fornecem epítopos específicos e únicos capazes de diferenciar os lissavírus em seus diferentes genótipos, por padrões de reação de anticorpos monoclonais (AcM) para estes epítopos (Wunner, 2007).

A $\mathrm{N}$ possui quatro sítios antigênicos (I a IV). A topografia dos sítios antigênicos comuns para todos os RABV e vírus aparentados, específicos para linfócitos $\mathrm{T}$ e $\mathrm{B}$, foram definidos nesta proteína usando inicialmente AcM e peptídeos sintéticos em ensaios competitivos (Lafon, Wiktor, 1985; Ertl et al., 1989). Subsequentemente muitos epítopos antigênicos lineares, sítios de ligação dos anticorpos, foram fisicamente mapeados na N. Três mapeados na região dos aa 358-367, o sítio antigênico I, e mais três em duas regiões: do aa 359 ao 366, e do aa 375 ao 383, sitio antigênico IV (Goto et al., 2000). Os epítopos encontrados entre os aa 359-366 são compartilhados pelos sítios antigênicos I e IV e refletem diferentes estados conformacionais de $\mathrm{N}$, a forma difusa pelo citoplasma e a forma associada com os corpúsculos de inclusões citoplasmáticas. Os epítopos encontrados entre os sítios I e IV também são conservados em todos lissavírus. Os sítios antigênicos II e III também são formados por epítopos conformacionais (Goto et al., 2000; Wunner, 2002).

$\mathrm{O}$ interesse pela característica imunológica da N surgiu da observação de que as RNP do RABV são capazes de induzir imunidade protetora em diversas espécies animais contra um desafio letal de vírus por via periférica (Dietzschold, et al., 1987). A proteína N é o principal antígeno para células $\mathrm{T}$ auxiliares $\mathrm{CD} 4+$ em diferentes variantes antigênicas do RABV e, 
também, entre os diferentes genótipos do gênero Lyssavirus (Lafon et al., 1992).Vários epítopos para células T auxiliares foram localizados entre os aa 404-418 (Ertl et al., 1989). Esta proteína não induz a produção de $\mathrm{AcN}$ do vírus, entretanto induz o aumento da produção de $\mathrm{AcN}$ dirigidos à proteína $\mathrm{G}$ (Fu et al., 1991).

A proteína P contém 297 aa e massa molecular de 38 a 41 kDa e é altamente conservada entre os lissavírus do genótipo I. A P interage com as proteínas $\mathrm{N}$ e L e acredita-se que atue como co-fator da RNA polimerase, sendo multifuncional, ligando-se a outras proteínas virais para auxiliar na replicação do genoma viral e interagir com fatores celulares, possivelmente na disseminação viral (Wunner, 2007).

A P atua como chaperona para as moléculas de $\mathrm{N}$ solúveis recém sintetizadas, impedindo a polimerização ou união com os RNAs que não sejam os do RABV, como também direciona a proteína N na encapsidação do RNA viral (Gigant et al., 2000; Mavrakis et al., 2003). Como uma subunidade do complexo RNA-polimerase, a P estabiliza a proteína L e direciona o complexo polimerase no molde de RNA, o que a L é incapaz de fazer sozinha (Chenick et al., 1994, 1998; Fu et al., 1994).

Outras interações que envolvem $\mathrm{P}$ estão relacionadas ao tropismo do RABV, à propagação do vírus célula a célula e à inibição da resposta imune inata, por inibição do fator regulador do interferon (IRF-3), que interfere ou cessa a replicação dos vírus (Wunner, 2007).

A proteína M do RABV e de outros genótipos de lissavírus é a menor das proteínas do virion contendo 202 aa e massa molecular de $25 \mathrm{kDa}$, apresentando-se em duas isoformas. A forma maior $\mathrm{M} \alpha$ representando $70-75 \%$ da proteína $M$ do virion e a forma $M \beta$, menor, representando 25 a 30\% do virion (Conzelmann, et al., 1990; Ameyama et al., 2003; Wunner, 2007). Aproximadamente 1200-1500 proteínas M se ligam ao core RNP, condensando-o e formando o arcabouço do virion. O tropismo da RNP pela membrana celular é determinado por esta proteína, possibilitando sua gemação (Mebatsion, Weiland, Conzelmann, 1999). Apesar da presença de M ligada na RNP ser responsável pela gemação do vírus, a interação desta proteína com $\mathrm{G}$, presente nas membranas celulares, estimula fortemente o processo (Mebatsion, Weiland, Conzelmann, 1999).

A proteína $\mathrm{G}$ do $\mathrm{RABV}$ é uma glicoproteína de membrana tipo I com sequência determinada de 505 aa e massa molecular de aproximadamente $65 \mathrm{kDa}$, sendo a proteína de fusão, atuando na adsorção viral a receptores específicos nas células dos hospedeiros, o que possibilita a entrada do vírus na célula. Além disso, é altamente imunogênica, sendo 
fundamental para a resposta imune contra o RABV, induzindo a produção de $\mathrm{AcN}$, ativação de linfócitos T auxiliares e T citotóxicos e atua na patogênese da doença (Wunner, 2007).

Pós-processada a proteína $\mathrm{G}$ é dividida em três regiões (domínios). O ectodomínio (EC), externo ao vírus e com 439 aa (1 a 439) da região N-terminal, o domínio transmembrana (TM), com 22 aa (440 a 461) e o endodomínio (ED) ou domínio citoplasmático, com 44 aa (462 a 505) da região C-terminal e situado no interior do vírus (Wunner, 2007).

O domínio TM é conservado, provavelmente por estar imerso no envelope do vírus, formado pela membrana plasmática dos diferentes hospedeiros. Esta conservação pode representar uma adaptação das linhagens do RABV adquirida durante o processo evolutivo vírus/hospedeiro. O domínio TM é "ancorado" na membrana celular e no envelope do vírus pelo segmento de aa 439 a 461 (Gaudin et al., 1992; Wunner, 2007).

O domínio ED é o mais conservado pelo fato de estar no interior do virion e ser a área de G responsável pela migração da RNP em direção a membrana celular, direcionada pelo citoesqueleto celular (Wunner, 2007).

O domínio EC de $\mathrm{G}$ é o menos conservado provavelmente pela pressão seletiva exercida pelo ambiente externo nesta área do vírus. A região EC é a mais imunogênica, estimulando tanto linfócitos B quanto linfócitos T auxiliares e T citotóxicos (Dietzschold et al., 1990; Kawai e Morimoto, 1994).

Epítopos estimuladores de linfócitos B e T foram localizados em G (Celis et al., 1988). Oito sítios antigênicos (I-VI, "a" e G1) foram mapeados no domínio EC. Os sítios antigênicos I, III, VI e "a" situam-se entre os aa 231, 330-338, 264 e 342-343, respectivamente. O sítio II é um sítio antigênico descontínuo que envolve dois segmentos separados de aa localizados nas posições 34-42 e 198-200, que provavelmente estão ligados por pontes de dissulfeto. Os sítios VI e G1 são lineares ou não conformacionais, enquanto os outros são conformacionais e facilmente destruídos por desnaturação (Wunner, 2007).

A RNA-polimerase L da cepa Pasteur Virus (PV) possui 2142 aa e o gene L ocupa, aproximadamente, 54\% do genoma do RABV (Wunner, 2007). A proteína L é o componente catalítico do complexo polimerase que, juntamente com o cofator $\mathrm{P}$, é responsável pela maioria das atividades enzimáticas que ocorrem tanto na transcrição quanto na replicação do genoma do RABV. Muitas das atividades deste complexo advêm de estudos com o Vírus da Estomatite Vesicular (VSV), o vírus protótipo da Família Rhabdoviridae. Além das atividades enzimáticas necessárias para a transcrição e replicação, L é responsável pelas modificações 
co-transcricionais dos mRNA, como por exemplo: 5'-capping, metilação e 3'-poliadenilação (Banerjee, Chattopadhyay, 1990).

\subsubsection{Organização genômica do $R A B V$}

O RABV apresenta um genoma não-segmentado de RNA fita-simples de polaridade negativa, com 11.932 nucleotídeos (nt). Os primeiros 58 nt, na extremidade 3', correspondem a uma sequência líder (Le) não codificante. Imediatamente após, estão localizados os cinco genes estruturais, $N, P, M, G e L$, os quais codificam as proteínas estruturais, $\mathrm{N}, \mathrm{P}, \mathrm{M}, \mathrm{G}$ e L, respectivamente. Estes genes apresentam-se separados por quatro regiões intergênicas não codificantes (entre o final 5' de um gene e o início 3' do próximo gene), sendo compostas de 2 nt (N-P), 5 nt (P-M), 5 nt (P-G) e 423 nt (G-L) (Wunner, 2007). Estas regiões têm importante papel na regulação da expressão gênica viral (Finke, Cox, Conzelmann, 2000). No final do genoma, existe uma sequência de 70 nt na região 5' denominada trailer (Tr) (Tordo et al., 1986a,b). As sequências Le e Tr apresentam papel chave nos processos de transcrição e replicação viral (figura 2) (Wunner, 2007).

Na família Rhabdoviridae, a longa região intergênica entre os genes $G$ e $L$, está presente apenas no gênero Lyssavirus, sendo denominada de gene remanescente ou o pseudogene viral $(\Psi)$ devido ao seu considerável tamanho e ausência de uma janela de leitura (orf) detectável (Tordo et al. 1986b). Esta região é a mais variável no genoma viral (Sacramento et al., 1991).

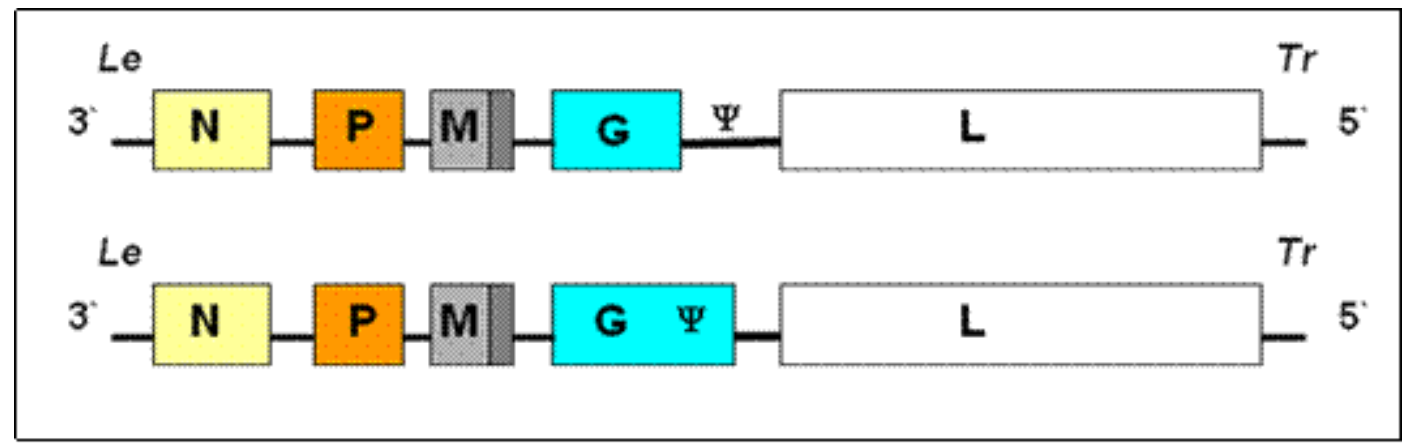

Figura 2 Representação esquemática da organização genômica do RABV. Acima para as cepas PV e ERA proposto por Tordo et al. (1986) Abaixo para as cepas HEP-Flury proposto por Morimoto, Ohkubo, Kawai, (1989), mostrando a integração da região não-codificante G-L dentro do gene que codifica para a glicoproteína do vírus.

Fonte: Morimoto, Ohkubo, Kawai, (1989). 


\subsubsection{Ciclo de replicação do $R A B V$}

Os eventos no ciclo de replicação do RABV na célula hospedeira são semelhantes aos de muitos outros vírus, ou seja: adsorção, penetração, transcrição, tradução, replicação, maturação e liberação por brotamento (gemação) (Fauquet et al., 2005). Todas as fases intracelulares ocorrem no citoplasma celular, motivo pelo qual o genoma do vírus possui o gene L. Os genes estruturais do vírus apresentam diferentes funções de acordo com o estágio da infecção (Wunner, 2007).

O primeiro evento da replicação viral é a adsorção do vírus na membrana da célula do hospedeiro mediada pela proteína G. Em seguida, o vírus penetra na célula por endocitose e ocorre a liberação das RNP no citoplasma celular, através da fusão do envelope viral ao vacúolo lisossomal. Após a liberação, é iniciada a transcrição do RNA viral nos cinco RNAs mensageiros de sentido positivo, na ordem N, P, M, G e L. A transcrição dos RNAs é realizada pela proteína L, que tem função de RNA polimerase - RNA dependente (Tordo, 1996).

Somente após a tradução das cinco proteínas virais tem início a replicação do genoma viral, também realizada pela proteína L. Primeiramente, ocorre a síntese do anti-genoma de sentido positivo, que servirá de molde para a produção do genoma viral de sentido negativo (Tordo, 1996).

Após a produção de suficiente número das proteínas virais N, P, L,M, G e também, de RNA genômico, ocorre a montagem do vírus (morfogênese). A formação das RNP, ou seja, a união de N, P e L ao RNA, ocorre simultaneamente ao deslocamento das proteínas M e G em direção a membrana celular para que, em seguida, ocorra a gemação do virion (Wunner, 2007). Estes eventos ocorrem enquanto a célula se mantém metabolicamente competente. A morfogênese viral está associada à formação de uma matriz intracitoplasmática, conhecida como corpúsculos de Negri, que antecede a formação dos novos virions (Matsumoto, 1962). Lahaye et al. (2009) obtiveram evidências que o corpúsculo de Negri pode ser o local de replicação e transcrição do RABV.

Nos estágios finais da morfogênese a pressão exercida pela RNP, nos locais onde G e M estão presentes, faz com que ocorra o revestimento do virion pela membrana da célula hospedeira, formando desta forma o envelope do RABV e, finalmente, liberando novas partículas infectantes (Gaudin et al., 1993). Na figura 3 está esquematizado o processo completo de replicação do RABV. 


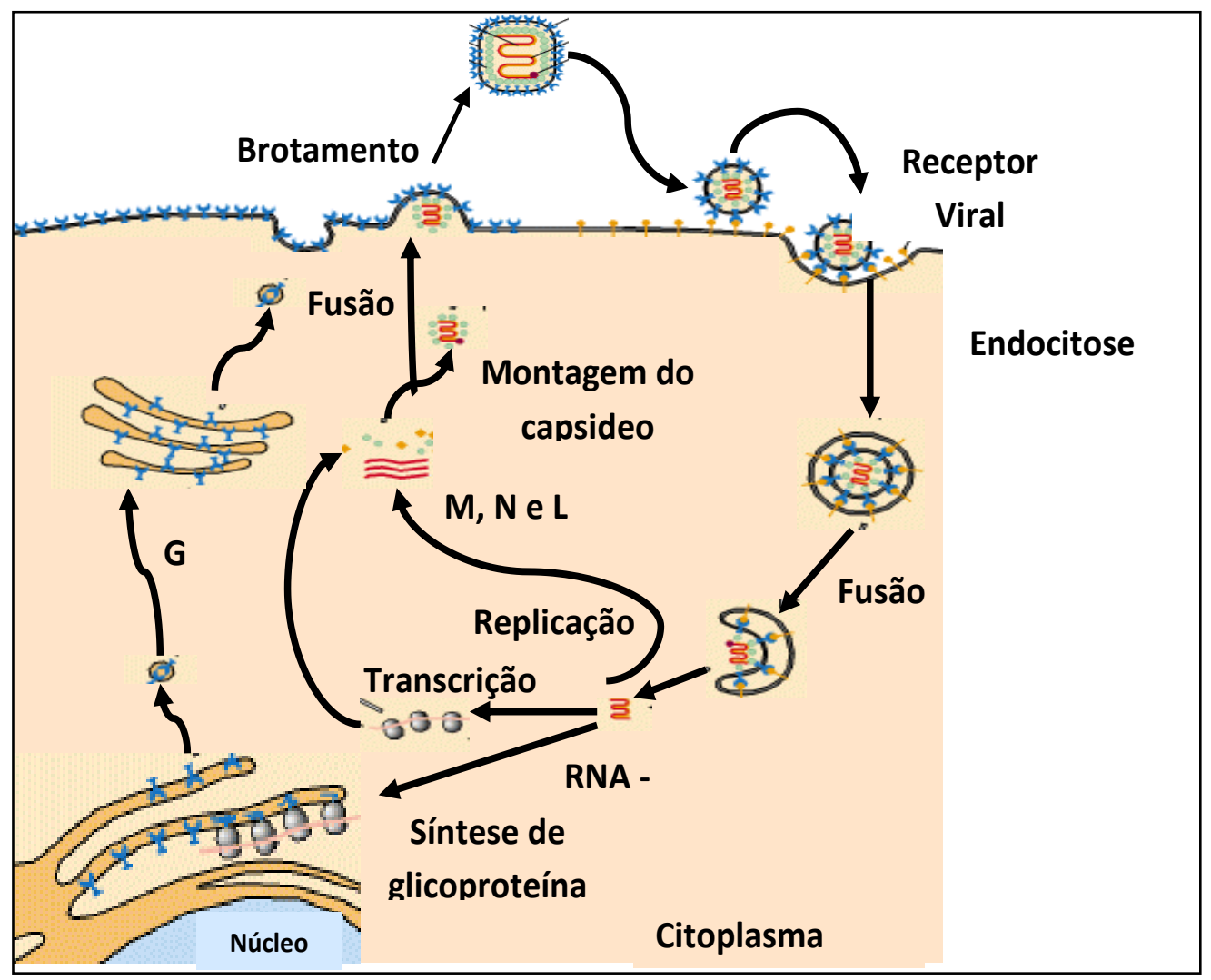

Figura 3. Representação esquemática do ciclo de replicação do vírus da raiva. Evidenciando processos de adsorção, penetração, replicação, maturação e saída de novas partículas virais infectantes. Fonte: Piere (2003).

\subsection{Epidemiologia da raiva}

A raiva é uma encefalite viral aguda, progressiva e fatal. A via de transmissão do vírus é a mordedura ou arranhadura e o contato do vírus contido na saliva com soluções de continuidade da pele do indivíduo agredido. Em raros casos de raiva em humanos, ocorreu transmissão por aerossóis, devido à permanência em cavernas habitadas por grande número de morcegos e transmissão por transplantes de órgãos de doadores infectados pelo vírus da raiva (Constantine, 1962; Srinivasan, et al., 2005; Jonhson et al, 2005; Center of Diseases Control and Prevention, 2004).

Anualmente, morrem aproximadamente 55.000 pessoas vítimas da raiva, principalmente em áreas rurais da África e da Ásia. O número de pessoas que recebe tratamento profilático após exposição a animal suspeito de infecção pelo vírus da raiva chega a dez milhões por ano (World Health Organization, 2006).

A raiva está difundida em todos os continentes, exceto na Antártida. Os lissavírus são muito instáveis e não conseguem permanecer viáveis no ambiente. Vários mamíferos têm 
servido de reservatórios em diferentes partes do mundo, principalmente os das ordens Carnivora e Chiroptera. O vírus da raiva tem sido isolado da maioria das ordens de mamíferos (Rupprecht, Hanlon, Hemachudha, 2002).

É fato que determinadas variantes e linhagens do RABV estão associadas a uma espécie animal, chamada de reservatório (Niezgoda, Hanlon, Rupprecht, 2002). A distribuição geográfica de uma determinada população viral associada com seu hospedeiro é determinada pela própria escala global da espécie animal bem como por aspectos de sua biologia, os quais determinam a extensão da interação entre diferentes subpopulações de hospedeiros. Portanto as variantes e linhagens do RABV circulam ao longo de um determinado território, o que permite identificá-las, pois estão adaptadas e são mantidas pelas diferentes espécies animais distribuídas regionalmente. Esta distribuição pode ser alterada se ocorrer a transmissão do vírus de um hospedeiro primário para um secundário ("spillover") e se esta nova população infectada mantiver a infecção ao longo do tempo, a área de distribuição do vírus é alterada, podendo ser ampliada (Childs, Real, 2007).

São admitidos dois ciclos de transmissão para a raiva, o ciclo urbano e o ciclo silvestre. O ciclo urbano tem o cão como principal reservatório e transmissor do vírus para outros cães, outros animais domésticos e para o homem. O ciclo silvestre é mantido por diferentes mamíferos silvestres terrestres e quirópteros (Acha, Szyfres, 2003).

Os cães ainda são os principais reservatórios da raiva nos países em desenvolvimento, porém, na Europa e América do Norte, onde os programas de vacinação em cães estão bem estabelecidos, o vírus da raiva mantém o seu ciclo principalmente nas espécies silvestres como raposas vermelhas, mangustos, guaxinins, gambás, chacais e morcegos (WHO, 2004).

No Brasil, no período de 1986 até setembro de 2008, ocorreram 761 óbitos por raiva humana, sendo que destes, 516 tiveram o cão como animal agressor, seguido dos quirópteros que foram responsáveis por 135 casos. Entre 1980 e 2003, houve uma redução significativa no número de casos de raiva humana registrados por ano, caindo de 173 para 17, representando uma diminuição de 91\% dos casos. De 2003 a 2008 foram notificados 104 casos de raiva humana em treze unidades federativas, sendo que $93 \%$ dos casos ocorreram nas regiões Norte e Nordeste do país. Nos anos de 2004 e 2005 foram 74 óbitos causados pela raiva, ocorridos nessas regiões, tendo como principal transmissor o morcego hematófago Desmodus rotundus. Em 2006 houve um decréscimo de 87,8\% nos casos de óbitos humanos por raiva e em 2007 ocorreu apenas um caso. Em 2008, dos três casos de raiva humana 
ocorridos, um recebeu tratamento baseado no protocolo de Milwaukee (Willoughby et al., 2005), que consiste no uso de antivirais e indução do paciente ao coma, o qual foi o primeiro caso de cura de raiva no Brasil. No ano de 2009 ocorram dois óbitos por raiva humana, sendo transmitidos por cão* (Figura 4) (Brasil, 2009).

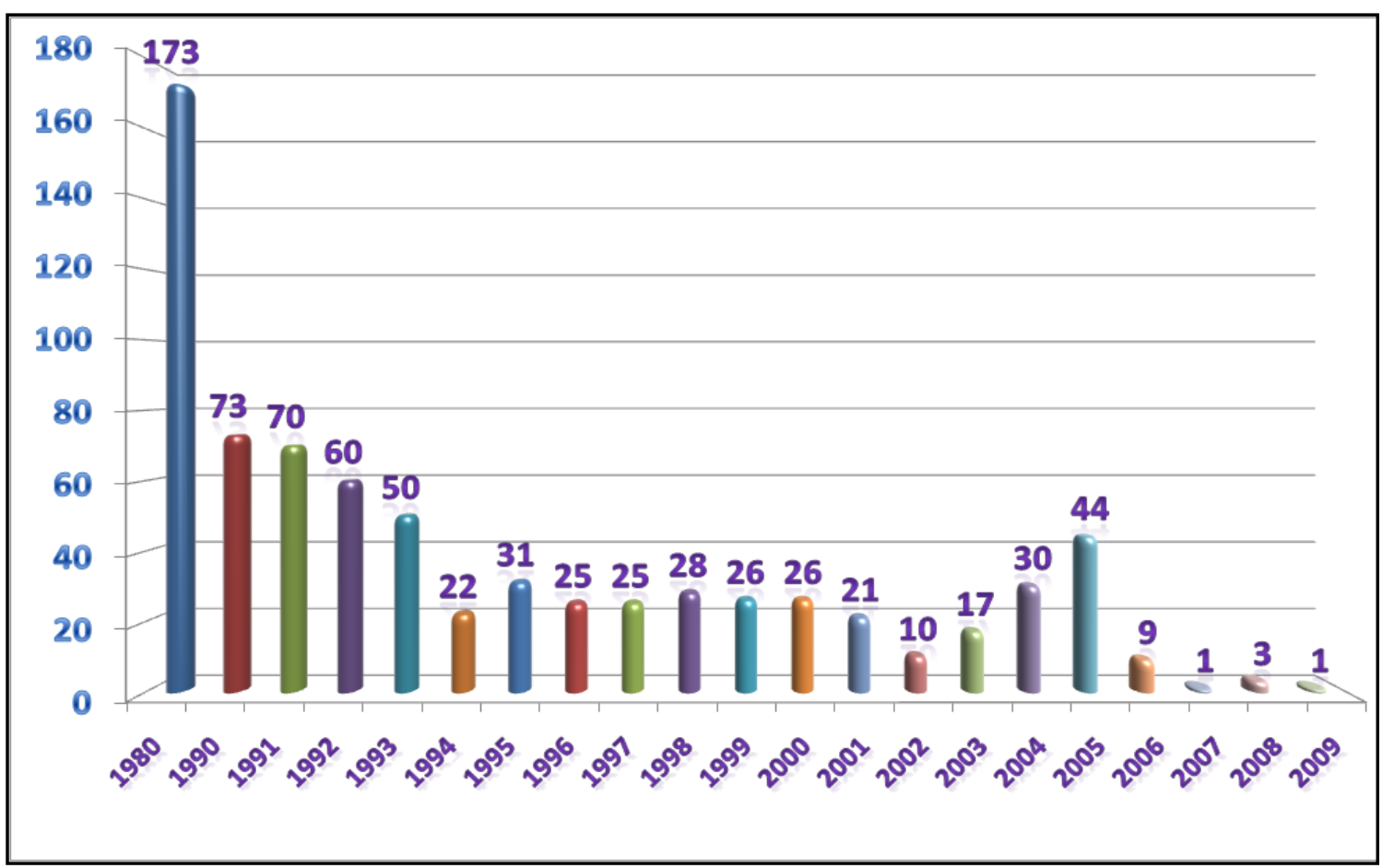

Figura 4. Casos de raiva humana diagnosticados no Brasil no período de 1980 a 2009.

\subsection{Diagnóstico laboratorial da raiva}

Os testes de diagnóstico laboratorial da raiva devem ser rápidos e precisos, uma vez que os resultados influenciam não só a decisão médica de instituir tratamento profilático em humanos, como também a elaboração de medidas de controle de uma possível epizootia em uma comunidade (Meslin, Kaplan, 1996).

As técnicas diagnósticas devem apresentar elevada sensibilidade e especificidade bem como rapidez na obtenção dos resultados. Portanto é recomendada na rotina laboratorial de diagnóstico a utilização de duas ou mais técnicas associadas, aumentando dessa maneira a confiabilidade dos resultados obtidos (Kotait, Carrieri, Takaoka, 2009).

As técnicas mais usadas no diagnóstico da raiva são imunofluorescência direta (IFD) e o isolamento do vírus por inoculação em animais ou em cultura de células. Os corpúsculos de Negri, detectados pela técnica histológica de Sellers, são inclusões intracitoplasmáticas patognomônicas da raiva formadas por RNP das partículas virais em maturação. As técnicas

\footnotetext{
* Dados cedidos pela Secretaria de Vigilância em Saúde do Ministério da Saúde - SVS/MS.
} 
histológicas apresentam menor grau de sensibilidade, pois dependem da experiência do observador (Kotait, Carrieri, Takaoka, 2009). O teste considerado "padrão ouro" para o diagnóstico laboratorial da raiva é a IFD, realizado em sistema nervoso central (SNC) de animais suspeitos de infecção pelo RABV e em testes que utilizam cultura de células para o isolamento viral (Rupprecht, Hanlon, Hemachuda, 2002). A rapidez, relativa facilidade de execução e economia faz deste teste o mais utilizado na maioria dos laboratórios para o diagnóstico da raiva do mundo (Dean et al., 1996). A IFD consiste em uma reação sorológica na qual, para se detectar a reação antígeno-anticorpo utiliza-se um sistema revelador, chamado conjugado, que é uma substância fluorescente (fluorocromo) ligada ao anticorpo. No diagnóstico da raiva as reações antígenos-anticorpos são visualizadas como partículas ou corpúsculos, ovalados ou arredondados emitindo luz de cor verde em microscópio de imunofluorescência (Webster, Casey, 1988; Dean et al.1996) .

O isolamento viral em animais, por inoculação intracerebral de suspensões das amostras, foi preconizado por Webster e Dawson em 1935. Apresenta alta sensibilidade, porém é demorado, pois o período de incubação do vírus é de 7 a 21 dias em camundongos albinos suíços, tem as desvantagens do uso de animais e o alto custo de manutenção dos mesmos.

A técnica de isolamento dos vírus em células de neuroblastoma murino (N2A) apresenta alta sensibilidade e especificidade, resultados obtidos em menor tempo (72 a 96 horas) e menor custo (Clark, 1978; King, 1996; Webster, Casey, 1996; Castilho et al., 2007).

\subsection{Estudos antigênicos e genéticos dos isolados de RABV}

A caracterização dos isolados de RABV se realiza atualmente pela caracterização antigênica com AcM, ou tipificação antigênica, e por sequenciamento genético. Estas técnicas não são procedimentos de rotina em laboratórios de diagnóstico da raiva, mas são técnicas complementares para a vigilância epidemiológica da doença, já que a identificação das diversas variantes do RABV está diretamente ligada aos reservatórios naturais que mantém a infecção circulando em áreas geográficas específicas (Organização Panamericana da Saúde, 1998).

A importância epidemiológica contida no mapeamento dos resultados obtidos por estas técnicas permite a observação da circulação das diversas variantes e seus reservatórios, informação muito útil para a prevenção da raiva animal e humana (OPS, 1998). 


\subsubsection{Caracterização antigênica - anticorpos monoclonais}

Em 1975, Köhler e Milstein descreveram a técnica para a produção de linhagens de células capazes de secretar AcM, chamadas de hibridomas, pois são formadas pela fusão de células de mieloma e linfócitos B. A imortalização das células B é adquirida pela fusão destas com as células de mieloma e o uso de meios seletivos. Desde então os AcM foram usados no estudo da imunologia e epidemiologia dos vírus, principalmente no RABV (Lafon, 1996).

O conceito de variantes antigênicas do RABV e o estudo das suas diferenças e reservatórios específicos foram consolidados com o desenvolvimento das técnicas de produção de AcM no final da década de 70. Estas técnicas foram utilizadas por Wiktor e Koprowski (1978) para produzir os primeiros hibridomas secretores de AcM contra as proteína $\mathrm{G}$ e $\mathrm{N}$ do RABV. Desde então os AcM foram amplamente utilizados para identificar e classificar o RABV e outros lissavírus em grupos correspondentes aos determinantes antigênicos (Wiktor, Koprowski, 1978; Flamand, Wiktor, Koprowski, 1980).

Diferentes painéis de AcM foram estabelecidos para permitir a diferenciação de RABV isolados de espécies terrestres e morcegos nos Estados Unidos da América e oeste da Europa, e em menor proporção na África, Ásia, leste da Europa e América Latina (Lafon, Lafage, 1987; Dietzschold et al., 1988; Vincent, Bussereau, Sureau, 1988; Smith, 1988; Schneider, Barnard, Schneider, 1985).

A capacidade discriminatória desse método baseia-se na habilidade de cada AcM de um painel reagir com um epítopo específico de uma proteína viral. De acordo com a sequência primária da proteína viral e, eventualmente, como consequência de modificações após a tradução da estrutura da proteína, o epítopo estará ou não presente, sendo assim, a reatividade do AcM será positiva ou negativa, respectivamente. Portanto, quanto mais epítopos puderem ser determinados com um painel de AcM, maior a probabilidade de melhorar a capacidade discriminatória do painel para a caracterização antigênica dos isolados. Aumentar a eficiência e a capacidade discriminatória de um painel exige não só um número significante de AcM, mas também assegurar que cada AcM que for incluído no painel liguese em epítopos independentes espaçados ao longo da extensão da proteína (Nadin-Davis, 2007).

Além da utilização dos AcM principalmente em investigações epidemiológicas, eles podem ser muito úteis para o diagnóstico da raiva em certas circunstâncias, tais como casos importados de raiva humana e casos de raiva associados com exposição incerta (Lumio et al., 
1986; Smith et al., 1991) e também rotineiramente em países com programas de vacinação oral de raposas em larga escala, no sentido de estabelecer que nenhuma infecção é causada pelo vírus vacinal (Schneider, Barnard, Schneider, 1985; WHO, 1984).

No período de 1982 a 1990 a Organização Mundial de Saúde (OMS) coordenou estudos colaborativos sobre o uso de AcM para o diagnóstico e pesquisa da raiva, direcionando ao estabelecimento de dois painéis de AcM, um permitindo a identificação de vários sorotipos de lissavírus e o outro permitindo a diferenciação das principais cepas de vírus vacinais daqueles isolados de reservatórios no campo. Um terceiro painel adicional foi selecionado também para diferenciar vírus da raiva de espécies animais terrestres isolados de espécies de morcegos da Europa (Meslin, Kaplan, 1996).

Para a caracterização antigênica por AcM, estão disponíveis vários painéis dos centros colaboradores da OMS e de instituições privadas, cada um com poder discriminatório diferente, portanto houve a necessidade de adotar um que fosse útil para a região das Américas (OPS, 1998).

Os centros de controles de doenças de vários países e o Centro Panamericano de Zoonoses (CEPANZO) da Organização Panamericana da Saúde (OPS) realizaram estudos, durante o período de 1987 a 1992, sobre diferentes isolamentos de vários países das Américas (Diaz, Rodriguez, Smith, 1994). Com esses dados selecionaram um painel de oito AcMs que permitem detectar as variantes mais comuns encontradas na América Latina. Este painel está disponível no centro colaborador da OMS, o "Centers of Diseases Control and Prevention" (CDC), Atlanta GA, EUA, para os laboratórios participantes do consórcio da OPS de laboratórios de referência em raiva das Américas (OPS, 1998).

O quadro 1 apresenta o painel do CDC para a caracterização antigênica, mostrando a reatividade dos oito AcM por meio da técnica de imunofluorescência indireta (IFI), a qual define 12 perfis antigênicos, que permitem estabelecer as 11 variantes antigênicas encontradas nos isolados da América Latina e diferenciá-las das cepas laboratoriais e vacinais: Challenge Virus Standard (CVS), Pasteur Virus (PV), Street-Alabama-Dufferin (SAD) e EvelynRokitnicki-Abelseth (ERA). 
Quadro 1 - Padrão de reações do painel de anticorpos monoclonais do CDC para caracterização das variantes antigênicas encontradas na América Latina

\begin{tabular}{|c|c|c|c|c|c|c|c|c|c|}
\hline \multirow{2}{*}{ Reservatório } & \multicolumn{8}{|c|}{ Padrão de reatividade com os seguintes AcMs } & \multirow{2}{*}{$\begin{array}{c}\text { Variantes } \\
\text { Antigênicas }\end{array}$} \\
\hline & C1 & C4 & C9 & C10 & $\mathrm{C12}$ & $\mathbf{C 1 5}$ & C18 & C19 & \\
\hline Cão / Mangusto & + & + & + & + & + & + & - & + & 1 \\
\hline Cão & + & + & - & + & + & + & - & + & 2 \\
\hline Desmodus rotundus & - & + & + & + & + & - & - & + & 3 \\
\hline Tadarida brasiliensis & - & + & + & + & + & - & - & - & 4 \\
\hline $\begin{array}{l}\text { Desmodus rotundus } \\
\text { Venezuela }\end{array}$ & - & + & $\mathrm{V}$ & + & + & V & - & V & 5 \\
\hline Lasiurus cinereus & V & + & + & + & + & - & - & - & 6 \\
\hline Raposa do Arizona & + & + & + & - & + & + & - & + & 7 \\
\hline $\begin{array}{c}\text { Cangambá Centro/Sul } \\
\text { EUA }\end{array}$ & - & + & + & + & + & + & + & + & 8 \\
\hline $\begin{array}{c}\text { Tadarida brasiliensis } \\
\text { México }\end{array}$ & + & + & + & + & + & - & - & - & 9 \\
\hline $\begin{array}{l}\text { Cangambá da Baixa } \\
\text { Califórnia/ México }\end{array}$ & + & + & + & + & - & + & - & + & 10 \\
\hline $\begin{array}{c}\text { Desmodus rotundus } \\
\text { México }\end{array}$ & - & + & + & + & - & - & - & + & 11 \\
\hline CVS/SAD/PV/ERA & + & + & + & + & + & + & + & + & $\begin{array}{c}\text { Cepa } \\
\text { laboratorial }\end{array}$ \\
\hline
\end{tabular}

(+) reação positiva; (-) reação negativa; (V) reatividade variável.

Fontes: (De Mattos CC, De Mattos CA, 1998; Diaz, Rodriguez, Smith, 1994; Delpietro et al., 1997).

\subsubsection{Caracterização genética do $R A B V$}

Os dados proporcionados pela análise da sequência de nt conjuntamente com a descrição epidemiológica da raiva humana e animal auxiliam na vigilância epidemiológica da doença. Substituições características de nt permitem a identificação das variantes do RABV que se encontram associadas aos diversos surtos. No entanto, a filogenia das variantes não tem muito valor sem a informação adequada sobre as circunstâncias em que ocorreram os eventos epidemiológicos, em particular a relação com reservatório e os fatores que contribuem para a manutenção da doença.

A transcrição reversa do ácido nucléico viral seguido da amplificação do DNA complementar, produzido por reação em cadeia pela polimerase (RT-PCR) e a análise posterior das sequências de nt no genoma viral constituem os elementos metodológicos para a 
identificação e diferenciação das variantes do RABV. Para os sequenciamentos, praticamente todos os laboratórios utilizam como alvo o gene N do RABV (OPS, 1998).

\subsubsection{As variantes antigênicas e genéticas da América Latina}

Na América Latina e no Caribe, os laboratórios de referência da Argentina, Brasil, Chile, Colômbia, México e Venezuela caracterizaram antigenicamente mais de 800 amostras isoladas de RABV, utilizando praticamente, em todos os países, o painel cedido pelo CDC, com exceção de 11 amostras isoladas na Argentina, nas quais se utilizou um painel fornecido pelo Instituto Wistar. A experiência acumulada na região revelou que o uso dessa técnica permitiu determinar a distribuição geográfica das diferentes variantes antigênicas do RABV, descrever novas variantes e identificar variantes conhecidas em novos hospedeiros, informações muito úteis para a vigilância epidemiológica da doença na região (OPS, 2000).

$\mathrm{Na}$ Argentina, a caracterização antigênica dos isolados do RABV na região identificou as variantes antigênicas $(\mathrm{AgV}) 2,3,4$ e 6 e esses resultados foram concordantes com a caracterização genética. Além dessas variantes também foram identificados, em isolados de morcegos insetívoros, outros perfis não compatíveis aos estabelecidos (Delpietro et al., 1997;. Cisterna et al., 2005).

Na Bolívia, quatro variantes antigênicas foram identificadas por tipificação antigênica dos isolados na região: $\mathrm{AgV} 1$ e 2, típicas de cão, e $\mathrm{AgV} 3$ e 5, típicas de morcegos hematófagos Desmodus rotundus. A identificação genética foi concordante com a antigênica, demonstrando haver três agrupamentos genéticos do RABV no país (Favi et al., 2003).

No Chile, vários estudos caracterizaram o morcego insetívoro Tadarida brasiliensis como o principal reservatório do RABV no país (De Mattos et al., 2000; Favi et al., 2002). Yung, Favi, Fernándes (2002) tipificaram antigenicamente e geneticamente isolados do RABV e identificaram as variantes $\mathrm{AgV} 3$ (D. rotundus), $\mathrm{AgV} 4$ (T. brasiliensis) e AgV6, típica do morcego insetívoro Lasiurus cinereus. Recentemente, um estudo retrospectivo com isolados do RABV do período de 1989 a 2005, identificou as variantes antigênicas AgV1, $\mathrm{AgV} 3, \mathrm{AgV} 4$ e AgV6 na maioria dos isolados, confirmando a importância de T. brasiliensis na epidemiologia da raiva no país. Nesse estudo alguns isolados não tiveram perfis de reatividade compatíveis com os do painel de AcM do CDC (Favi et al, 2008).

$\mathrm{Na}$ Venezuela, as variantes $\mathrm{AgV} 1,3$ e 5 foram identificadas nos isolados de RABV no país, o que foi confirmado pela caracterização genética concordante (De Mattos et al., 1996). 
Em várias ilhas do Caribe, como por exemplo, Cuba e República Dominicana a variante 1 do RABV isolada em mangustos (Herpestes auropunctatus) é a predominante. Atualmente, os mangustos são os principais transmissores do RABV nessa região americana (Blanton et al., 2006).

Desde 1996, o laboratório de diagnóstico da raiva do Instituto Pasteur de São Paulo (IP/SP) faz a caracterização antigênica de vírus isolados de diferentes espécies animais de várias regiões do Brasil, utilizando o painel de oito AcM contra a nucleoproteína viral, produzido pelo CDC de Atlanta - EUA e definido pela OPS. Uma análise feita em 330 isolados de diferentes espécies entre 1996 e 2000 demonstrou 5 variantes antigênicas compatíveis aos perfis observados no painel pré-estabelecido, duas em cães AgV1 e AgV2 e três em morcegos, AgV3 de D. rotundus, AgV4 de Tadarida brasiliensis e AgV6 de Lasiurus spp. Foram identificados ainda outros seis perfis não compatíveis com o painel utilizado. A maior variabilidade foi observada entre as amostras isoladas de morcegos insetívoros e a variante mais comum isolada entre as espécies foi a variante 3 de D. rotundus (Favoretto et al., 2002).

Existem duas outras variantes distintas que circulam no Brasil, na região Nordeste e que têm como reservatórios o Cerdocyon thous (cachorro do mato) e o Callithrix jacchus (sagui-do-tufo-branco) e não são compatíveis com as definidas pelo painel do CDC, porém possuem um perfil antigênico constante (Favoretto et al., 2001, 2006; Carnieli et al., 2006, 2008).

A observação da incompatibilidade de certos isolados exigiu a complementação dos estudos antigênicos com análises genéticas, as quais têm comprovado a diversidade dos isolados de RABV no Brasil. Estes isolados, confirmados como variantes antigênicas, pertencem todos ao Genótipo 1 do gênero Lyssavirus, assim como todos os demais isolados no continente americano e Caribe (Ito et al., 2001; Kobayashi et al., 2005).

No período de 2000 a 2006, o laboratório de diagnóstico do IP/SP analisou 4057 amostras de morcegos encontrados em áreas urbanas da cidade de Ribeirão Preto, no estado de São Paulo, das quais 64 foram positivas para raiva e eram de espécies de hábitos frugívoros ou insetívoros. O estudo antigênico desses isolados pelo painel de AcM identificou a maioria dos isolados como variantes $\mathrm{AgV} 3$ e $\mathrm{AgV} 6$, e dois não compatíveis com o painel (Carrieri et al., 2006). 
Albas et al. (2009) caracterizaram antigenicamente 18 isolados de morcegos não hematófagos provenientes do oeste do estado de São Paulo, e foram detectadas as variantes antigênicas AgV3 de D. rotundus e AgV4 de T. brasiliensis.

Das 167 espécies de morcegos existentes no Brasil, o RABV já foi isolado de 37 espécies (Kotait et al., 2007). Destas, aproximadamente 62\% possuem hábito alimentar insetívoro.

O IP/SP recebe anualmente cerca de 4.000 amostras de morcegos para o diagnóstico da raiva. Em 2008, 42 morcegos foram diagnosticados positivos para raiva. Todos os isolados de morcegos foram submetidos à caracterização antigênica por IFI utilizando o painel do CDC e pelo menos 24 foram incompatíveis com os perfis de reação determinado pelo painel. Em 2009, foram diagnosticados 60 morcegos positivos para a raiva e destes aproximadamente 19 apresentaram perfis não compatíveis com os pré-estabelecidos pelo painel do $\mathrm{CDC}^{\dagger}$.

Oliveira (2009) realizou a análise genética de isolados de RABV de diversas espécies de morcegos insetívoros do estado de São Paulo a partir de sequências parciais dos genes $N$ e $G$ e encontrou linhagens específicas de RABV para os gêneros Myotis, Eptesicus e Nyctinomops e três prováveis linhagens circulantes nos gêneros Tadarida, Histiotus e Lasiurus. Para as três linhagens de RABV circulantes em morcegos insetívoros dos gêneros Myotis, Eptesicus e Nyctinomops também foram identificados marcadores moleculares específicos para as proteínas $\mathrm{N}$ e G putativas, que permitem sua distinção de outras linhagens do RABV, contribuindo para um melhor entendimento da relação entre o RABV e gêneros diversos de quirópteros.

Nos últimos anos um grande número de morcegos, de espécies com hábitos alimentares insetívoros, diagnosticados positivos para raiva no IP/SP, quando caracterizadas antigenicamente cerca de 30 a 40\% desses não apresentaram perfis compatíveis com o painel utilizado. Portanto faz-se necessária a ampliação desse painel de AcM para caracterização de novas variantes antigênicas, possibilitando assim o melhor conhecimento dos vírus circulantes nessas espécies, contribuindo para uma vigilância epidemiológica mais eficaz da doença no Brasil.

\footnotetext{
${ }^{\dagger}$ Dados fornecidos pelo Laboratório de Diagnóstico da Raiva do Instituto Pasteur de São Paulo
} 


\section{CONCLUSÕES}

- A adaptação dos isolados de vírus da raiva de morcegos insetívoros, amostras 7268V/05 e 636V/06 à cultura de células N2A foi bem sucedida,

- $\quad$ o que propiciou a concentração das RNP desses isolados para serem usados como imunógenos;

- $\quad$ e também favoreceu a adaptação da técnica imunofluorescência indireta em cultura de células de neuroblastoma murino (N2A) para uso como método de seleção dos hibridomas produtores de AcM;

- Dois hibridomas produtores de anticorpos monoclonais contra o vírus da raiva foram produzidos, a partir da fusão dos linfócitos dos linfonodos poplíteos de camundongo imunizado com RNP do isolado 636V/06, o AcM 3A7 e o AcM 4E10;

- A caracterização dos monoclonais obtidos mostrou serem do isótipo IgG subtipo IgG2a, com especificidade para epítopos do vírus expressos em células neurais (epítopos conformacionais), sem atividade de neutralização viral;

- Os AcMs obtidos reagiram com a maioria dos isolados caracterizados como variante antigênica 3 (Desmodus rotundus). O AcM 3A7 reagiu com oito (61,53\%) e o 4E10 com onze $(84,61 \%)$. Dos nove isolados com perfil não compatível, característico de isolados de morcegos insetívoros $(\mathrm{C} 4+, \mathrm{C} 10+, \mathrm{C} 12+)$, o AcM 3A7 reagiu com $5(55,55 \%)$ e o AcM 4E10 com $4(44,44 \%)$. 


\section{REFERÊNCIAS ${ }^{*}$}

Acha PN, Szyfres B. Zoonoses y enfermedades transmisibles comunes al hombre y a los animales. 3rd. ed. Washington: Organization Panamericana de la Salud, 2003;2:351-383.

Albas A, Souza EA, Lourenço RA, Favoretto SR, Sodré MM. Antigen profile of rabies virus isolated from different species of non-hematophagous bats in the region of Presidente Prudente, State of São Paulo. Rev Soc Bras Med Trop. 2009;42(1):15-17.

Ameyama S, Toriumi H, Takahashi T, Shimura Y, Nakahara T, Honda Y, Mifune K, Uchiyama T, Kawai A. Monoclonal antibody 3-9-16 recognizes one of the two isoforms of rabies virus matrix protein that exposes its $\mathrm{N}$-terminus on the virion surface. Microbiol Immunol. 2003;47(9):639-651.

Arai YT, Kuzmin IV, Kameoka Y, Botvinkin AD. New Lyssavirus Genotype from The Lesser Mouse - Eared Bat (Myotis Blythi), Kyrghystan. Emerg Infect Dis. 2003;9(3):333-337.

Badrane, H, Bahloul, C, Perrin, P, Tordo, N. Evidence of two lyssavirus phylogroups with distinct pathogenicity and immunogenicity. J Virol. 2001;3268-3276.

Baer GM. History of the Rabies. In: Jackson AC; Wunner WH editors. Rabies. San Diego: Academic Press; 2007. p.1-22.

Baer GM, Belli WJ, Fishbein DB. Rhabdoviruses, In: Fields BN, Knipe DM. Virology, New York: Raven; 1990. p.883-930.

Banerjee AK, Chattopadhyay D. Structure and function of the RNA polymerase of vesicular stomatitis virus. Adv Virus Res. 1990;38:99-124.

Batista AM, Cruz PS, Almeida E, Costa AEB, Scheffer KC, Chaves LB, Silva ACR, Caporale GMM. Infecção de células BHK-21 cultivadas em monocamadas estacionárias por cepas de vírus PV e CVS. BEPA. 2009;6(71):4-11.

Bernardi F, Nadin-Davis SA, Wandeler AI, Armstrong J, Gomes AA, Lima FS, Nogueira FR, Ito $\mathrm{FH}$. Antigenic and genetic characterization of rabies viruses isolated from domestic and wild animals of Brazil identifies the hoary fox as a rabies reservoir. J Gen Virol. 2005;86(11):3153-3162.

Blanton JD, Meadows A, Murphy SM, Manangan J, Hanlon CA, Faber ML, Dietzschold B, Rupprecht CE. Vaccination of small Asian mongoose (Herpestes javanicus) against rabies. J Wildl Dis. 2006;42(3):663-666.

Botvinkin AD, Poleschuck EM, Kuzmin IV, Borisova TI., Gazaryan SV, et al. Novel lyssavirus isolated from bats in Russian. Emerg Infect Dis. 2003;9(12):1623-1625.

Bourhy H, Kissi B, Tordo N. Molecular diversity of the Lyssavirus genus. Virology. 1993;194:70-81.

Bradford MM, A rapid and sensitive method for the quantitation of microgram quantities of protein utilizing the principle of protein-dye binding. Anal Biochem. 1976;72:248-254.

\footnotetext{
*De acordo com:

International Committee of Medical Journal Editors. Uniform requirements for manuscripts submitted to Biomedical Journals: sample references. Available from: http://www.icmje.org[2007 May 22].
} 
Brasil. Ministério da Saúde. Secretaria de Vigilância em Saúde. Departamento de Vigilância Epidemiológica. Manual de diagnóstico laboratorial da raiva. Brasília: Ministério da Saúde; 2008. 108p.

Brasil. Ministério da Saúde do Brasil. Secretaria de Vigilância em Saúde/ [homepage on internet] Vigilância Epidemiológica. Raiva. Casos da doença no Brasil. Disponível em http://portal.saude.gov.br/portal/arquivos/ casos_conf_raiva.pdf. [julho 2009].

Caporale GMM, Silva ACR, Peixoto ZMP, Chaves LB, Carrieri M., Vassão, RC. First production of fluorescent anti-ribonucleoproteins conjugate for diagnostic of rabies in Brazil. J Clin Lab Anal. 2009;23(1):7-13.

Carnieli P Jr, Fahl WO, Castilho JG, Oliveira Rde N, Macedo CI, Durymanova E, Jorge RS, Morato RG, Spíndola RO, Machado LM, Ungar de Sá JE, Carrieri ML, Kotait I. Characterization of Rabies virus isolated from canids and identification of the main wild canid host in Northeastern Brazil. Virus Res. 2008 Jan;131(1):33-46.

Carnieli P Jr, Brandão PE, Carrieri ML, Castilho JG, Macedo CI, Machado LM, Rangel N, de Carvalho RC, de Carvalho VA, Montebello L, Wada M, Kotait I. Molecular epidemiology of rabies virus strains isolated from wild canids in Northeastern Brazil. Virus Res. 2006;120(12):113-120.

Carrieri ML, Oliveira RN, Canello FM, Castilho JG, Carnielli Jr P, Achkar SM et al. Bats rabies in the period between 2000-2006, in Ribeirão Preto County, São Paulo State, Brazil. In: Reunião Internacional de Raiva nas Américas (RITA) XVII; Brasilia- Brasil; 2006. Anais... Ministério da Saúde; 2006. p115.

Castilho JG, Canello FM, Scheffer KC, Achkar SM, Carrieri ML, Kotait I. Antigenic and genetic characterization of the first rabies virus isolated from the bat Eumops perotis in Brazil. Rev Inst Med trop São Paulo. 2008 Mar-Apr; 50(2):95-9.

Castilho JC, Iamamoto K, Lima JYO, Scheffer KC, Carnieli Jr, P; Oliveira RN, Macedo CI, Achkar SM, Carrieri ML, Kotait I. Padronização e aplicação da técnica de isolamento do vírus da raiva em células de neuroblastoma de camundongo (N2A). BEPA. 2007;4(47):12-18.

Celis E, Karr RW, Dietzschold B, Wunner WH, Koprowski H. Genetic restriction and fine specificity of human T cell clones reactive with rabies virus. J Immunol. 1988;141(8):2721-8.

Center of Disease Control and Prevention (CDC). Investigation of rabies infections in organ donor and transplant recipients - Alabama, Arkansas, Oklahoma, and Texas, 2004. MMWR. 2004 Jul 9;53(26):586-589.

Chenik M, Chebli K, Gaudin Y, Blondel D. In vivo interaction of rabies virus phosphosprotein $(\mathrm{P})$ and nucleoprotein $(\mathrm{N})$, existence of two $\mathrm{N}$ binding sites on $\mathrm{P}$ protein. $\mathrm{J}$ Gen Virol. 1994;75:2889-96.

Childs JE, Real LA. Epidemiology. In: Jackson AC, Wunner WH editors. Rabies. San Diego: Academic Press; 2007. p.123-199.

Cisterna D, Bonaventura R, Caillou S, Pozo O, Andreau ML, Fontana LD, Echegoyen C, De Mattos C, De Mattos C, Russo S, Novaro L, Elberger D, Freire MC. Antigenic and molecular characterization of rabies virus in Argentina. Virus Res. 2005;109(2):139-147.

Clark HF. Rabies viruses increase in virulence when propagated in neuroblastoma cell culture. Science. 1978 Mar 10;199(4333):1072-1075. 
Clark HF. Rabies serogroup viruses in neuroblastoma cells: propagation, "autointerference," and apparently random back-mutation of attenuated viruses to the virulent state. Infect Immun. 1980 Mar; 27(3):1012-1022.

Constantine DG. Rabies transmission by no byte route. Public Health Rep. 1962;77:287-289.

Conzelmann KK, Cox JH, Schneider LG, Thiel HJ. Molecular cloning and complete nucleotide sequence of the attenuated rabies virus SAD B19. Virology. 1990;175(2):485-499.

Dean DJ, Abelseth MK, Atanasiu P. The fluorescent antibody test. In:Meslin FX;Kaplan MM, Koprowski H, editors. Laboratory techniques in rabies. 4th ed. Geneva: WHO. 1996. p.88-95.

Dean DJ, Baer GM, Thompson WR. Studies on the Local Treatment of Rabies - Infected Wounds. Bull Wld Hlth Org. 1963;28:477-486.

Delagneau JF, Perrin P, Atanasiu P. Structure of rabies virus: Spatial relation-ships of the proteins G, M1, M2 and N. Ann L'Institut Pasteur: Virol. 1981;132E:473-493.

Delpietro HA, Gury-Dhomen F, Larghi OP, Mena-Segura C, Abramo L. Monoclonal antibody characterization of rabies virus strains isolated in the River Plate Basin. Zentralbl Veterinarmed B. 1997;44(8):477-483.

De Mattos CA, Favi M, Yung V, Pavletic C, De Mattos CC. Bat rabies in urban centers in Chile. J of Wild Dis. 2000;36: 231-240.

De Mattos CC, De Mattos CA. Uso de anticuerpos monoclonales para La tipificación antigénica da aislamientos de virus rábico. In: Organización Panamericana de La Salud. Consorcio de La OPS de laboratorios de referencia en rabia de las Américas. Washington, DC Bases para la operación. HCP/HCV/R2/015; 1998. p.2-11.

De Mattos CA, De Mattos CC, Smith JS, Miller ET, Papo S, Utrera A.et al. Genetic characterization of rabies field isolates from Venezuela. J. of Clinic Microb. 1996;34:15531558 .

Diaz AM, Rodriguez A, Smith JS. Antigenic analysis of rabies-virus isolates from Latin America and the Caribbean. J of vet med B, Infect Dis and Vet Public Hlth. 1994;41:153-160.

Dietzschold B. Techniques for the purification of rabies virus, its subunits and recombinant products. In: Meslin F-X., Kaplan MM, Koprowski H, editors. Laboratory techniques in rabies. 4th ed.: Geneva.World Health Organization. 1996. p.175-180.

Dietzschold B, Gore M, Marchadier D, Niu HS, Bunschoten HM, Otvos L Jr, Wunner WH, Ertl HC, Osterhaus AD, Koprowski H. Structural and immunological characterization of a linear virus-neutralizing epitope of the rabies virus glycoprotein and its possible use in a synthetic vaccine. J Virol. 1990;64(8):3804-3809.

Dietzschold B, Rupprecht CE, Tollis M, Lafon M, Mattei J, Wiktor TJ et al. Antigenic diversity of the glycoprotein and nucleocapsid proteins of rabies and rabies-related viruses: implications for epidemiology and control of rabies. Rev. Infect. Dis. 1988;10:785-798.

Dietzschold B, Wang HH, Rupprecht CE, Celis E, Tollis M, Ertl H, Heber-Katz E, Koprowski $\mathrm{H}$. Induction of protective immunity against rabies by immunization with rabies virus nucleoprotein. Proc Natl Acad Sci USA. 1987;84(24):9165-9169.

Ertl HC, Dietzschold B, Gore M, Otvos L Jr, Larson JK, Wunner WH, Koprowski H. Induction of rabies virus-specific T-helper cells by synthetic peptides that carry dominant Thelper cell epitopes of the viral ribonucleoprotein. J Virol. 1989;63(7):2885-2892. 
Fauquet CM, Mayo MA, Maniloff J, Desselberger U, Ball LA. Virus taxonomy. In: Eighth Report of the International Committee on Taxonomy of Viruses. San Diego: Academic Press; 2005. p.630-634.

Favi CM, Rodríguez AL, Espinosa MC, Yung PV. Rabies in Chile: 1989-2005. Rev Chilena Infectol. 2008;25(2):8-13.

Favi M, Nina A, Yung V, Fernández J. Characterization of rabies virus isolates in Bolivia. Virus Res. 2003;97(2):135-140.

Favi M, De Mattos CA, Yung V, Chala E, López LR, De Mattos CC. First case of human rabies in Chile caused by an insectivorous bat virus variant. Emerg Infect Dis. 2002;8(1):7981.

Favoretto SR, de Mattos CC, de Morais NB, Carrieri ML, Rolim BN, Silva LM, Rupprecht CE, Durigon EL, de Mattos CA. Rabies virus maintained by dogs in humans and terrestrial wildlife, Ceará State, Brazil. Emerg Infect Dis. 2006;12(12):1978-1981.

Favoretto SR, Carrieri, ML, Cunha, ES, Aguiar, EAC, Silva LHQ, Sodré MM et al. Antigenic typing of brazilian rabies virus samples isolated from animals and humans, 1989-2000. Rev. Inst. Med. trop. S. Paulo. 2002;44 (2):91-95.

Favoretto SR, de Mattos CC, Morais NB, Alves Araújo FA, de Mattos CA. Rabies in marmosets (Callithrix jacchus), Ceará, Brazil. Emerg Infect Dis. 2001;7(6):1062-1065.

Favoretto SR, Carrieri ML, Tino MS, Zanetti CR, Pereira OA. Simplified fluorescent inhibition microtest for the titration of rabies neutralizing antibodies. Rev Inst Med Trop Sao Paulo. 1993 Mar-Apr;35(2):171-5.

Finke S, Cox JH, Conzelmann KK. Differential transcription attenuation of rabies virus genes by intergenic regions: Generation of recombinant viruses overexpressing the polymerase gene. J Virol. 2000;74(16):7261-7269.

Flamand A, Wiktor TJ, Koprowski H. Use of hybridoma monoclonal antibodies in the detection of antigenic differences between rabies and rabies-related viral proteins. I. The nucleocapsid protein. J Gen Virol. 1980;48:97-109.

Fooks AR. The challenge of new and emerging lyssaviruses. Expert. Rev. Vaccines. 2004;3(4):333-336.

Fu ZF, Dietzschold B, Schumacher CL, Wunner WH, Ertl HC, Koprowski H. Rabies virus nucleoprotein expressed in and purified from insect cells is efficacious as a vaccine. Proc Natl Acad Sci USA. 1991;88(5):2001-2005.

Fu ZF, Zheng Y, Wunner WH, Koprowski H, Dietzschold B. Both the N- and the C-terminal domains of the nominal phosphoprotein of rabies virus are involved in binding to the nucleoprotein. Virology. 1994;200(2):590-597.

Gaudin Y, Ruigrok RW, Tuffereau C, Knossow M, Flamand A. Rabies virus glycoprotein is a trimer. Virology. 1992;187(2):627-632.

Gaudin Y, Ruigrok RW, Knossow M, Flamand A. Low-pH conformational changes of rabies virus glycoprotein and their role in membrane fusion. J Virol 1993;67(3):1365-1372.

Gigant B, Iseni F, Gaudin Y, Knossow M, Blondel D. Neither phosphorylation nor the aminoterminal part of rabies virus phosphoprotein is required for its oligomerization. J Gen Virol. 2000;81:1757-1761. 
Goto H, Minamoto N, Ito H, Ito N, Sugiyama M, Kinjo T, Kawai A. Mapping of epitopes and structural analysis of antigenic sites in the nucleoprotein of rabies virus. J Gen Virol. 2000;81:119-127.

Gould AR, Hyatt AD, Lunt R, Kattenbelt JA, Hengstberger S, Blacksell SD. Characterization of a novel lyssavirus isolated from pteropid bats in Australia. Virus Res. 1998;54:165-187.

Hanna JN, Carney IK, Smith GA, Tannenberg AE, Deverill JE, Botha JA, Serafin IL, Harrower BJ, Fitzpatrick PF, Searle JW. Australian bat lyssavirus infection: a second human case, with a long incubation period. Med. J. Aust. 2000;172:597-599.

Hooper PT, Lunt RA, Gould AR, Samaratunga H, Hyatt AD, Gleeson LJ, Rodwell BJ, Rupprecht CE, Smith JS, Murray PK. A new lyssavirus - the first endemic rabies-related virus recognized in Australia. Bull Inst Pasteur. 1997;95:209-218.

Ito M, Arai YT, Itou T, Sakai T, Ito FH, Takasaki T, Kurane I. Genetic characterization and geographic distribution of rabies virus isolates in Brazil: identification of two reservoirs, dogs and vampire bats. Virology. 2001;284(2):214-222.

Johnson N, Brookes SM, Fooks AR, Ross RS. Review of human rabies cases in the UK and in Germany. Vet Rec. 2005;157(22):715.

Kawai A, Morimoto K. Functional aspects of lyssavirus proteins in lyssaviruses. Curr Top Microbiol Immunol. 1994;187:27-42.

Kearney JF, Radbruch A, Liesegang B, Rajewsky K. A new mouse myeloma cell line that has lost immunoglobulin expression but permits the construction of antibody-secreting hybrid cell lines. J Immunol. 1979;123(4):1548-50.

King AA. Cell culture of rabies virus. In: Meslin FX, Kaplan MM, Koprowski H. editors Laboratory techniques in rabies. 4th ed. Geneva: WHO; 1996. p. 80-87.

King A. European bat rabies. Sixth SEARG meeting, Lilongwe/Malawi 2001;96-100.

Kobayashi Y, Sato G, Shoji Y, Sato T, Itou T, Cunha EM, Samara SI, Carvalho AA, Nociti DP, Ito FH, Sakai T. Molecular epidemiological analysis of bat rabies viruses in Brazil. J Vet Med Sci. 2005;67(7):647-652.

Köhler G, Milstein C. Continuos culture of fused cells secreting antibody of predefined specificity. Nature, 1975;256:495-497.

Koprowski H. The mouse inoculation test. In: Meslin FX, Kaplan MM, Koprowski H. Laboratory techniques in rabies. 4th ed. Geneva: WHO; 1996. p.80-87.

Kotait I, Carrieri ML, Carnieli Jr P, Castilho JG, Oliveira RN, Macedo CI, Ferreira KCS, Achkar SM. Reservatórios silvestres do vírus da raiva: um desafio para a saúde pública. BEPA. 2007;4(40),2-8.

Kotait I, Carrieri ML, Takaoka NY. Manual técnico do Instituto Pasteur. vol. 8. Raiva: aspectos gerais e clínica. São Paulo: Instituto Pasteur, 2009. 49p.il.

Kuzmin IV, Botvinkin AD, Khabilov TK. The lyssavirus was isolated from a whiskered bat in northern Tajikistan. Plecotus, 2001;4:75-81.

Kuzmin IV, Orciari LA, Arai YT, Smith JS, Hanlon CA. Bat lyssaviruses (Aravan and Khujand) from Central Asia: phylogenetic relationships according to N. P. and G genes sequences. Virus Research. 2003;97(2):65-79. 
Lafon M, Techniques for the production, screening and characterization of monoclonal antibodies. In Meslin F. X. Khaplan, M. M., Koprowski H. ed., Laboratory techniques in rabies, 4th ed. Geneva, Switzerland: WHO; 1996,133-144.

Lafon M, Lafage M, Martinez-Arends A, Ramirez R, Vuillier F, Charron D, Lotteau V, ScottAlgara D. Evidence for a viral superantigen in humans. Nature. 1992;358(6386):507-10.

Lafon, M., Lafage, M. Antiviral activity of monoclonal antibodies specific for the internal proteins N and NS of rabies virus. J Gen Virology. 1987;68:3113-3123.

Lafon M, Wiktor TJ. Antigenic sites on the ERA rabies virus nucleoprotein and nonstructural protein. J Gen Virol. 1985;66:2125-33.

Lumio J, Hillbom M, Roine R, Keonen L, Haltia M, Valle M, Neuvonen E, Lahdevirta J. Human rabies of bat origin in Europe. Lancet. 1986;1(8477):378.

Lahaye X, Vidy A, Pomier C, Obiang L, Harper F, Gaudin Y, Blondel D. Functional characterization of Negri bodies (NBs) in rabies virus infected cells: evidence that NBs are sites of viral transcription and replication. J Virol, 2009;83(16):7948-58.

Matsumoto, S. Electron microscopy of nerve cells infected with street rabies virus. Virology 1962;17:198-202.

Mavrakis M, Iseni F, Mazza C, Schoehn G, Ebel C, Gentzel M, Franz T, Ruigrok RW. Isolation and characterization of the rabies virus N-P complex produced in insect cells. Virology 2003;305(2):406-14.

Mebatsion T, Weiland F, Conzelmann KK. Matrix protein of rabies virus is responsible for the assembly and budding of bullet-shaped particles and interacts with the transmembrane spike glycoprotein G. J Virol. 1999;73(1):242-50.

Meslin FX, Kaplan MM. An overview of laboratory techniques in the diagnosis and prevention of rabies and in rabies research. In Meslin FX. Kaplan, MM, Koprowski H. editors. Laboratory techniques in rabies, 4th ed. Geneva, Switzerland: WHO; 1996. p. 9-27.

Morimoto K, Ohkubo A, Kawai A. Structure and transcription of the glycoprotein gene of attenuated HEP-Flury strain of rabies virus. Virology. 1989;173(2):465-477.

Murphy FA. Morphology and morphogenesis. In: Baer GM. editors. The Natural History of Rabies. Boca Raton: CRC. Press; 1991. p.33-61.

Nadin-Davis SA. Molecular epidemiology. In: Jackson AC, Wunner WH. editors. Rabies, 2nd ed. San Diego: Academic Press; 2007. p.69 -122.

Niezgoda M, Hanlon CA, Rupprecht CE. Animal rabies. In: Jackson AC, Wunner WH. editors Rabies. San Diego: Academic Press; 2002. p. 163-218.

Oliveira RN. Vírus da raiva em morcegos insetívoros: implicações em epidemiologia molecular da diversidade dos genes codificadores da nucleoproteína e glicoproteína. [dissertação (Mestrado em Medicina Veterinária)] São Paulo (Brasil): Faculdade de Medicina Veterinária e Zootecnia da Universidade de São Paulo; 2009.

Organización Panamericana de la Salud. OPS. Consorcio de la OPS de laboratórios de referencia en rabia de las Américas. Bases para la operación. HCP/HCV/R2/015; 1998; p43.

Organización Panamericana de la Salud. OPS. Los anticuerpos monoclonales en la caracterización y vigilancia de los virus de la rabia en América Latina y el Caribe. Rev. Panam Salud Publica/ Pan Am J Public Health. 2000;8(3):214-217. 
Perrin P, Lafon M, Versmisse P. Aplication d'une méthode immunoenzymatiqueau titrage des anticorps rabiques neutralisants en culture cellulaire. J Bio Standard. 1985;13:35-42.

Piere KMS. Caracterização de Amostras de Vírus Rábico Isoladas no Estado de Santa Catarina através de anticorpos monoclonais e PCR de baixa estringência. [dissertação (Mestrado em Biotecnologia)]. São Paulo (Brasil): Departamento de Microbiologia e Parasitologia da Universidade Federal de Santa Catarina; 2003.

Pounder DJ. Rabies, lyssavirus and bats. Scott Med J. 2003;48(4):99-101.

Pringle CR. The order mononegavirales. Arch Virol. 1991;117:137-140.

Rotivel Y, Goldal M, Perrin P, Tordo N. Une historie de la vaccination contre la rage. Virologie. 2002;6:89-104.

Rudd RJ, Trimarchi CV. Development and evaluation of an in vitro virus isolation procedure as a replacement for the mouse inoculation test in rabies diagnosis. J Clin Microbiol. 1989 Nov; 27(11):2522-2528.

Rudd RJ, Trimarchi CV. Comparison of sensitivity of BHK-21 and murine neuroblastoma cells in the isolation of a street strain rabies virus. J Clin Microbiol. 1987 Aug; 25(8):14561458.

Rudd RJ, Trimarchi CV, Abelseth MK. Tissue culture technique for routine isolation of street strain rabies virus. J Clin Microbiol. 1980 Oct; 12(4):590-593.

Rupprecht CE, Dietzschold B, Wunner WH, Koprowski H. Antigenic relationship of lyssaviruses. In: Baer GM. editor The Natural History of Rabies. Boca Raton: CRC. Press; 1991. p. 33-61.

Rupprecht CE, Hanlon CA, Hemachudha T. Rabies re-examined. The Lancet Infect Dis. 2002;2:327-343.

Sacramento D, Bourhy H, Tordo N. PCR techniques as an alternative method for diagnosis and molecular epidemiology of rabies virus. Mol Cell Probes. 1991;5(3):229-40.

Schaefer R, Batista HB, Franco AC, Rijsewijk FA, Roehe PM. Studies on antigenic and genomic properties of Brazilian rabies virus isolates. Vet Microbiol. 2005;107(3-4):161-170.

Schneider LG. Antigenic variants of rabies virus. Comp Immunol Microbiol Infect Dis. 1982;5:101-107.

Schneider LG, Barnard BJH, Schneider HP. Application of monoclonal antibodies for epidemiological investigations and oral vaccination studies. I. African viruses. II. Artic viruses. III. Oral rabies vaccine. In: Kuwert E, Merieux C, Koprowski H, Bogel K. editors Rabies in the tropics. Berlin: Springer-Verlag; 1985. p.47-59.

Schneider LG. Concentration and purification. In: Baer GM, editor. The Natural History of rabies.. New York: Academic Press; 1975. p.125-140.

Schneider LG, Dietzschold B, Dierks R. E., Matthaeus W, Enzmann PJ, Strohmaier K. Rabies group-specific ribonucleoprotein antigen and a test system for grouping and typing of rhabdoviruses. J Virol. 1973;11:748-755.

Shulman M, Wilde CD, Köhler G. A better cell line for making hybridomas secreting specific antibodies. Nature. 1978;276:269-270.

Smith, J.S. Molecular epidemiology. In: Rabies (A.C. Jackson and W.H. Wunner, editors. San Diego: Academic Press; 2002. p. 79-111. 
Smith JA, Yanger PA, Baer GM. Rapid fluorescent focus inhibition test for determinig rabies virus-neutralizing antibody. In: Meslin, FX; Kaplan, MM; Koprowski, H. editors Laboratory techniques in rabies. Genebra: WHO 1996. p.181-192.

Smith JS, Fishbein DB, Rupprecht CE, Clark K. Unexplained rabies in three immigrants in the United States. A virologic investigation. New Eng J of Med. 1991;324:205-211.

Smith, JS. Monoclonal antibody studies of rabies in insectivorous bats of the United States. Rev Infect Dis. 1988;10(4):637-643.

Srinivasan A, Burton EC, Kuehnert MJ, Rupprecht C, Sutker WL, Ksiazek TG, Paddock CD, Guarner J Shieh WJ et al. Transmission of rabies from an organ donor to four transplant recipients. N Eng J Med. 2005;352:1103-1111.

Steelle JH, Fernandez PJ. History of Rabies and Global Aspects. In: Baer GM. The Natural History of rabies. 2nd ed. New York: Academic Press; 1991. p.1-24.

Theodorides J. Histoire de la Rage. Eds Fondaction Singer-Polignac (Masson); 1986. p.25.

Tordo, N. Characteristics and molecular biology of the rabies virus. In Meslin FX, Kaplan MM, Koprowski H. editors. Laboratory techniques in rabies, 4th ed. Geneva, Switzerland: WHO; 1996. p.28-51.

Tordo N, Kouknetzoff A. The rabies virus genome: an overview. Onderstepoort J Vet Res. 1993;60(4):263-269.

Tordo N, Poch O, Ermine A, Keith G, Rougeon NF. Primary struture of leader RNA and nucleoprotein genes of the rabies genome: segmented homology with VSV. Nucl Acid Res. 1986a; $14: 2671-2683$.

Tordo N, Poch O, Ermine A, Keith G, Rougeon F. Walking along the rabies genome: is the large G-L intergenic region a remnant gene? Proc Natl Acad Sci USA. 1986;83(11):39143918.

Towbin H, Staehelin T, Gordon J. Electrophoretic transfer of proteins from polyacrylamide gels to nitrocellulose sheets: procedure and some applications. Proc Natl Acad Sci USA. 1979 Sep; 76(9):4350-4354.

Velasco-Villa A, Gómez-Sierra M, Hernandez-Rodriguez G, Juárez-Islas V, Meléndez-Félix A, Vargas-Pino F, Velázquez-Monroy O, Flisser A. Antigenic diversity and distribution of rabies virus in Mexico. J of Clinic Microbiol. 2002;40:951-958.

Vincent J, Bussereau F, Sureau P. Immunological relationships between rabies virus and rabies-related viruses studied with monoclonal antibodies to Mokola virus. Ann. Inst.Pasteur/Virol. 1988;139:157-173.

Webster LT, Dawson JR, Early diagnosis of rabies by mouse inoculation. Measurement of humoral immunity to rabies by mouse protection test. Proc Soc Experiment Bio an Med.1935;32:570-573.

Webster WA, Casey GA Virus isolation in neuroblastoma cell culture. In:Meslin FX;Kaplan MM, Koprowski H, editors. Laboratory techniques in rabies. 4th ed. Geneva: WHO. 1996. p. 96-104.

Wiktor TJ, Aaslestad HG, Kaplan MM. Immunogenicity of rabies virus inactivated by $\beta$ propiolactone, acetylethyleneimine, and ionizing irradiation. Appl Microbiol. 1972 May; 23(5):914-918 
Wiktor TJ, Clark HF. Chronic rabies virus infection of cell cultures. Infect Immun. 1972 Dec; 6(6):988-995.

Wiktor TJ, Dietzschold B, Leamnson RN, Koprowski H. Induction and biological properties of defective interfering particles of rabies virus. J Virol. 1977 Feb; 21(2):626-635.

Wiktor TJ, Flamand A, Koprowski H. Use of monoclonal antibodies in diagnosis of rabies virus infection and differentiation of rabies and rabies-related viruses. $J$ Virol Meth. 1980;1:33-46.

Wiktor TJ, Koprowski H. Antigenic variants of rabies virus. J Exp Med. 1980;152:99-112.

Wiktor TJ, Koprowski H. Monoclonal antibodies against rabies virus produced by somatic cell hybridization: detection of antigen variants. Proc Nat Acad Sci Wash. 1978;75:39383942.

Wild TF, Bijlenga G. A rabies virus persistent infection in BHK-21 cells. J Gen Virol. 1981 Nov; 57(Pt1):169-177.

Wilkinson L. History of Rabies. In: Jackson AC, Wunner WH editors Rabies. New York: Academic Press; 2002. p.1-22.

Willoughby RE Jr, Tieves KS, Hoffman GM, Ghanayem NS, Amlie-Lefond CM, Schwabe MJ, Chusid MJ, Rupprecht CE. Survival after treatment of rabies with induction of coma. N Engl J Med. 2005 Jun 16;352(24):2508-2514.

World Health Organization. WHO. Expert Consultation on Rabies. First Report. Geneva: WHO; 2004. (Technical Report Series, 931). Available from: http://www.who.int/rabies/ trs931_\%2006_05.pdf

World Health Organization. WHO Expert committee on Rabies, Seventh report. Geneva, 1984; (WHO Technical Report Series, $n^{\circ}$ 709):58-60.

World Health Organization. WHO. Rabies. Available from: http:/www.who.int/mediacentre/ factsheets/ fs099 [cited $2006 \mathrm{dez} 22$ ].

Wunner WH, Larson JK, Dietzschold B, Smith CL. Review of Infect Dis. 1988;10,(4):771784.

Wunner WH. Rabies Virus. In: Jackson AC, Wunner WH, editors. Rabies, San Diego: Academic Press, 2002. p.23-71

Wunner WH. Rabies virus. In: Jackson AC, Wunner WH, editors. Rabies, second edition. San Diego: Academic Press, 2007. p.23-68.

Yokoyama WM, Christensen M, Santos G, Miller D. Production of monoclonal antibodies. In: Coligan JE, Biere BE, Margulies DH, Shevach EM, Strober W, Coico R, editors. Current protocols in immunology. John Wiley \& Sons; 2006. p.251-252.

Yung V, Favi M, Fernández J. Genetic and antigenic typing of rabies virus in Chile. Brief report. Arch Virol. 2002;147(11):2197-2205.

Zanluca C. Produção e caracterização de anticorpos monoclonais contra o vírus rábico. [dissertação (mestrado em Biotecnologia)] Florianópolis (Brasil): Departamento de Microbiologia e Parasitologia da Universidade Federal de Santa Catarina; 2010.

Zinke, G. Neue Ansichten der Hundswuth, ihre Ursachen und Folgen, nebst einer sichern Behandlungsart der von tollen Tieren gebissenen Menschen. Jena Review. 1804;16:212-218. 